\title{
The Teacher's Beliefs and Practices on the Use of Digital Comics in Teaching Writing: A qualitative case study
}

Muflikhatun Nisa Muyassaroh, Abdul Asib, \& Sri Marmanto

The Graduate School of English Department, Universitas Sebelas Maret, Surakarta, Indonesia

Email corresponding author: muflikhatun7nisa@gmail.com

How to cite this paper: Muyassaroh, $M$. N., Asib, A., \& Marmanto, S. (2019). The Teacher's Beliefs and Practices on the Use of Digital Comics in Teaching Writing: A qualitative case study. International Journaı of Language Teaching and Education, 3(1), 45-60.

https://doi.org/10.22437/ijolte.v3i1.6502

Accepted: May 09, 2019

Published: July 31, 2019

Copyright (C) 2019 International Journal of Language Teaching and Education

This work is licensed under the Creative Commons Attribution International License (CC BY 4.0). http://creativecommons.org/license s/by/4.0/

\section{(i)}

\begin{abstract}
In the industrial era 4.0, the use of digital comic as a multimodal teaching medium is seen as the new trend in EFL classrooms. Although many teachers had already used this medium, so far, the exploration of the use of digital comics for teaching writing in vocational school has not been extensively investigated yet. This study aimed to explore teacher beliefs, practices, and problems in implementing digital comics to teach writing for vocational students. This medium implemented by using the genre approach. This study used a qualitative case study approach. The subject was an experienced English teacher who held M. A. in English language. One of the interesting findings, the teacher, believed that the implementation of comics was the best method to switch the vocational students' stereotype on English; from English as the most challenging subject to English as the enjoyable subject. However, as a consequence, the combination of digital comics and process approach confronted a major challenge, namely time management.
\end{abstract}

\section{Subject Areas \\ Teaching Writing}

Keywords

Digital comics, descriptive and recount writing, belief, and practices, teacher professional identity

\section{INTRODUCTION}

In the industrial era 4.0, the use of digital comic as a teaching medium seen as the new trend in EFL classrooms. Comics, as a multimodal composition, has far-reaching benefits for preparing learners to respond cogently and adeptly to $21^{\text {st }}$-century composition demands (Issa, 2017). In Indonesia, EFL latest books contain realistic images of students' activities with actions and social relations (Elmiana, 2019). Even more, the significant influence of comics is argued as a post-facto reason for linguistic change because it contains unusual speech patterns (Unser-Schutz, 2015).

Digital comics are electronic comics which are distributed and screened digitally (Ferdiansyah, 2018; Jang \& Song, 2017; Susilawati, 2017; Winarti, Masrupi, \& Juniardi, 2018). Based on its forms, at least, digital comics are distinguished into two: online and offline. Many of these online comics can 
be downloaded or printed. From this process, online comics have changed to become offline comics.

Rozema (2015) mentioned that comics (or manga in Japanese term) cover a wide range of genres for its readers, including girls, boys, women, and men. Based on its categories, there are fantasy, school life, romance, comedy, tragedy, historical, supernatural, horror, science, fiction, gender bender, etc. Commonly, one comic may contain some categories. For instance, one of the popular comics entitled Naruto is classified as the boy's comics, which its story involves fiction, ninja-school life, and comedy. Each of the comics' genre or category is the representation of the author's point of view and set of belief (Park, 2016).

This popularity was used by some EFL teachers to engage their students in creating a positive atmosphere during the teaching-learning process. As a teaching medium, many teachers applied comics to teach the reading skill (Liu, 2004). Since comics contains images and texts, this medium quickly attracted EFL students' attention (Januarty \& Azizah Nima, 2018). It also became a useful tool to foster students meaning-making and reading comprehension (McGrail, Rieger, \& Doepker, 2017). Its positive use in EFL learning enhances the comics' popularity.

On the other side, some comics may include controversial contents such as cyberbullying, suicide, domestic violence (Jang \& Song, 2017), and also LGBT characters (Abate, Grice, \& Stamper, 2018; Baudinette, 2017; Galvan, 2018; Howard, 2018; Kedley \& Spiering, 2017; Vega, 2015). Considering these sensitive contents, the adaptation of comics as a teaching medium is not an easy decision. The teachers, who prefer to use this medium than other media, should be careful and aware of its consequences because this kind of comics is appropriate only for adult learners. Adolescent and young learners may face difficulty to understand or use of this genre of comics for learning writing.

In EFL learning, it is known that there are three main approaches in teaching writing namely product approach, process approach, and genre approach (Jang \& Song, 2017; Nordin, 2017; Osman, 2017). First, the product approach aims to teach EFL learners on how to create a sophisticated text by imitating a given pattern. Second, as the opposite, the process approach instead concentrates on how a text is written through the back-and-forth cycles of prewriting, drafting, evaluating, and revising. Third, compared to the two other approaches, the genre process approach emphasizes the learners to create texts based on social contexts (Badger \& White, 2000). In Indonesia context, the English teaching in schools commonly applies a scientific approach which follows the K-13 as the current national curriculum of the Ministry of Education.

Teachers' considerations to implement a particular approach are mainly affected by their beliefs. Richardson (1996) defined the teacher's belief as an individual's thought or understanding of classroom practices, change, and learning to teach. Furthermore, he divided this belief into two groups. First, teachers' belief about education is difficult or impossible to change, and second, teachers' belief about education can change depending on the content and nature of influences that one undergoes. Beijaard et al. (2000) argued that there were three influential factors of teachers' belief, such as teaching context, teaching experience, and the biography of the teacher. These elaborations indicate that a teacher's belief may change if the teacher experiences a new thing in a relatively long period. 
His/her cognitive view possibly interlinks the teacher's belief on a particular phenomenon. Beiijaard et al. (2000) described teacher professional identity as of his/her understanding of their own professional identity. It covers three domains, such as: the teacher as a subject matter expert (a teacher who bases his/ her profession on subject matter knowledge and skills), the teacher as a pedagogical expert (a teacher who bases his/ her profession on knowledge and skills to support students' social, emotional, and moral development), and the teacher as a didactical expert (a teacher who bases his/her profession on knowledge and skills regarding the planning, execution, and evaluation of teaching and learning process).

All in all, these were some relevant studies towards comics between 2014 and 2019. First, after the use of comics in the classroom, Johnson (2016) and Susilawati (2017) succeed to gain their students writing ability. Second, according to the students' perceptions, Yusof, Lazim, and Salehuddin (2017) found that they were excited when the graphic novel was introduced in their class mainly because it had more pictures than words. Third, according to the teachers' perceptions, Cheung (2015) recognized that not all of those teachers used comics frequently. Moreover, some of them were confronted by difficulties (e.g., adapting to Japanese comics' right-to-left reading sequence) during its implementation as a teaching medium. This indicated that the use of comics as a teaching medium could not guarantee the improvement of students' writing ability if the teachers have difficulties towards the medium. Fourth, McGrail et al. (2017) found that comics was a powerful medium for enhancing decoding skills, which contained contextual clues. Empirically, these findings proved that there were some advantages and disadvantages to using comics as a teaching medium.

Despite the controversy of comics, this medium had already implemented and inquired in some degrees of institution: kindergarten (McGrail et al., 2017), elementary (Deligianni-Georgaka \& Pouroutidi, 2016; Johnson, 2016; McGrail et al., 2017; Yusof et al., 2017), junior-high (Rokhayani \& Utari, 2014), senior-high (Anggraini, 2014; Cheung, 2015; Susilawati, 2017; Winarti et al., 2018) and university (Kim, 2018). Although many teachers had already used this medium, so far, the exploration of the use of digital comics in vocational high school has not been extensively investigated yet.

Interestingly, the researchers found that there is an experienced English teacher who used comics as the medium to teach his vocational students. The present study aimed to explore the implementation of teaching writing by using comics in vocational high school. The research question was, How are the experienced teacher's beliefs on the implementation of digital comics associated with the teaching practices?

\section{METHOD}

This study took the site in one of vocational high school in Boyolali, Central Java Province, Indonesia. The subject was an English teacher in this school, namely Mr. Ryan (a pseudonym), who regularly used comics as a medium to teach his students during three recent years. He had already taught this vocational school for nearly10 years. He also held M. A. in English language.

The researchers applied a qualitative single case-study approach. Yin (2014) stated that this design 
focused on investigating a unique or temporary case in-depth within its real-world context.

The data were obtained from three sources, such as participants, events, and documents. First, the participants were Mr. Ryan and his students who experienced in using comics in their classes. Their data were elicited through semi-structured interviews. Second, the event was the teachinglearning process where comics implemented in the grade $10^{\text {th }}$ and $11^{\text {th }}$ classrooms. In collecting the data, the first researcher became the observer in two classrooms ( 1 classroom of the grade $10^{\text {th }}$ and one classroom of the $11^{\text {th }}$ grade). Each of these classes consisted of 30 students. In total, the observations were conducted eight times or four times for each class. A video recorder recorded all observations. Third, the documents were Mr. Ryan's syllabus, the lesson plans, the comics, and the students' writing tasks. These data were gathered with the help of Mr. Ryan.

To ensure the credibility, the researchers used member-check and triangulation processes. Firstly, the member-check was conducted after the researchers transcribed the interviews. Each of interviewees was given the result of interview transcripts. They needed to confirm that the interview transcripts were consistent with the interview sessions. Secondly, the triangulation was applied after the member-check process. It aimed to corroborate the same finding from the data which were obtained from multiple sources (e.g. interviews, observations). For instance, one of the sub-finding themes, namely the implementation of digital comics was developed inductively from the teacher's interview transcript. Next, this theme was confirmed by the observation note, which discussed the same theme. Last, it was verified by the teacher's lesson as the document data.

As explained by Yin (2014), there were five general strategies to analyze data. For this study, the researchers applied two of them, namely pattern matching and explanation building. First, identifying the teacher's belief and its influential factors based on the interview transcripts. Second, all transcriptions were analyzed inductively to develop several (sub) themes. The themes of the interviews and the observations were crossly checked to integrate the corresponding data. Meanwhile, the documents (e.g., lesson plans) were used as the supplementary data to support the data. Third, the researchers started to elaborate on the results, then compare it to previous studies, and interpret it based on the relevant theories.

\section{FINDING AND DISCUSSION}

To ease the explanation of the results and the discussion, this part was divided into four points i.e. the belief on the characteristic digital comics for language learning, the belief on teaching English writing in vocational schools, the strategy to maximizing the use of digital comics, and the difficulties encountered by the students and the teacher.

\subsection{The belief of the characteristics of digital comics for language learning}

The teacher believed that the use of comics is the best method to switch the vocational students' stereotype on English; from English as the most challenging subject to English as an enjoyable subject. This stereotype rose because those students are middle-low learners.

"Based on the background of vocational students, they are middle-low learners who considered that English as 
one of the most difficult for them, then, my belief towards the use of comics, as a method to change the students' mind, in order to help them realized that English is not a difficult subject and more enjoyable to learn." (Mr. Ryan. Interview 1. August 2017)

This finding was congruent with the previous studies (Cheung, 2015; Johnson, 2016) where the middle-low learners needed a particular treatment (e.g., using new media such as comics or graphic novels) in order to help them in confronting their learning difficulties. This kind of learners was not only found in vocational school but also from various degrees; from elementary to university students, private and public institutions. For the teachers of these learners, changing the negative stereotype became more important than teaching skills and knowledge. One of the most advantages of comics was this media used simple sentences and exciting plots which did not burden the students in their learning.

"Because comics are seen as a straightforward book which does not use complex sentences, the simplification of sentences in comics would help the students to learn meanings and story's plots, that is why they would not feel burdened in learning English." (Mr. Ryan. Interview 1. August 2017)

Indeed, there were other media (e.g., magazines) which also used simple sentences. However, those media were not persuasive enough like comics. Mr. Ryan confessed that he liked and collected comics. Although previously he used to read comics books, now he preferred to read digital comics because it was more efficient. Either the comics are in printed version or a digital version, Mr. Ryan still liked to read comics. Indeed, it was clear that reading comics is Mr. Ryan's hobby. His hobby was somewhat unique, but he did not have any intention to hide it.

“...fortunately I also like comics, whatever its kinds. I have some collections. However, recently, I used to read it online, efficient, and simple. (Mr. Ryan. Interview 1. August 2017)

Compared than magazines and novels, comics were considered as the most appropriate media to learn specific English. As argued by Kiss and Wagner (2016), by persuasively connecting visual and linguistic information to their existing schemas and through a complex process of comparing and contrasting, the students made new, unique, meaning and cultural understandings. First, for instance, the visual represents how the characters act in various situations. Second, the short-texts represent the conversations among characters and the atmospheres (e.g., sounds) of settings. The combination of these two produces a life story which is easily absorbed by the students' imagination. It is more than what one wants to say, but also 'how' one wants to say it. Surprisingly, Mr. Ryan and his students shared the same interest, i.e. comics. He noticed it when he saw his students brought comics to the school, and they hid them inside their bags and drawers.

"1 did not choose comics from out of nowhere; in a glance, I saw that the students seemed to like comics. I knew it when there was a school inspection; it was found that, in their bags, there were so many comics." (Mr. Ryan. Interview 1. August 2017)

This unintentional event strengthened Mr. Ryan's decision to apply comics as teaching media. Even more, by demonstrating his interest in students, it also helped him to engage a good relationship with them (Beijaard et al., 2000). This finding supported Ferdiansyah (2018) that facilitating the enhancement of students' background knowledge played a vital role in assisting them to comprehend 
the genre of the text.

Besides the printed comics, Mr. Ryan also liked to read online comics. His hobby enriched his knowledge on the variety of comics' genres (e.g., adults $21+$ ). He needed it because he should select and recommend which comics are appropriate for his students.

"...yes sometimes I like to read comics online. So I did understand that the comics genres are varied; it also has many adult genres. I also knew which one of these digital comics which are is appropriate for my students." (Mr. Ryan. Interview 1. August 2017)

This finding was congruent with Cheung (2015), where the teacher had 'an insider knowledge' because of his familiarity towards comics as an inspirational book. Knowledge of comics' genres is vital for any teacher who plans to use comics in his/her class. The adults' genres are not appropriate for vocational high school learners. Teachers should be knowledgeable and learn many things; not only about their subject (Utami \& Prestridge, 2018). Unfortunately, these genres can be easily accessed through digital comics by using smartphones. Therefore, during its implementation, the teacher needs to supervise students while they are accessing digital comics. Last but not least, Mr. Ryan also changed his hairstyle into Japanese style to act like the character in comics. This action supported to create an enjoyable atmosphere in his class.

"I used Japanese comics, and it means that I put Japanese features into the teaching-learning process, I also tried to change my hairstyle became Japanese style. Surprisingly, my students were more interested in following my writing class." (Mr. Ryan. Interview 1. August 2017)

This finding supported Salcedo and Sacchi (2014) that culture teaching was positive in teaching-learning activities because it gained students' motivation for diverse cultures. Despite Mr. Ryan's spontaneous action, this action succeeded to gain the students' attention. Indirectly, it showed that the teacher had already built a mutualism relationship with his students where the teacher accommodated the students' interest, and the students gave their attention to the teacher during the teaching-learning process.

\subsection{The belief in teaching English writing in vocational schools}

This belief was gained from the teacher's personal experiences as a vocational school student and his current professional experiences as a language teacher.

On the one side, from his perspective, Mr. Ryan believed that English is not a difficult subject to learn because he had exciting experiences. While he was studying in vocational school as a student, he was regarded as a high achiever since he had several achievements in English competitions. He enjoyed learning English because his teachers could conduct an enjoyable atmosphere by providing some attractive ways of teaching. Nevertheless, he felt that the situation did not occur in writing class because of less attractive stimulation. It impacted his writing skill, which was not better than his speaking ability. 
"...I am one of the alumni of this school, so I knew very well, how the characteristics of vocational students and their English learning are. At that time, I liked English very much, and I was frequently asked, as the school representative, to join competitions. It possibly happened because my teacher was able to create an enjoyable learning atmosphere. However, I did not know why, when the English learning talked about writing texts, I and my friends were bored. Then I thought, maybe, his stimulations to encourage us to write were insufficient. Finally, my writing was not good at that time."(Mr. Ryan. Interview 1. August 2017)

Mr. Ryan, as a vocational student, was able to hold a positive belief towards English learning. Because his English teacher was a good example, he was able to enjoy and master English since his school period. This experience also inspired Mr. Ryan to be a teacher. This finding was by Gabinete (2017) and American and Pouromid (2018) that teachers' early education experience played a significant role in shaping certain beliefs.

On the other side, from his professional perspective, Mr. Ryan got many new insights into English teaching regarding the development of students' writing skill during his undergraduate study. He obtained them by accomplishing a set of coursework. Also, he performed a set of plans to prepare himself in learning. He applied various media in his teaching to suit it with the materials.

"During my undergraduate, my knowledge about teaching is continuously expanding. I knew that 'ideal' is the goal, based on technical standards. Indeed, it should be like that, so did in teaching writing. When the time came, I frequently changed my teaching media over and over, included this comic to teach writing. Yeah, it should be matched with materials and circumstances. At first, I doubt it too, because all manga (i.e., Japanese comics) are produced by Japan, not American." (Mr. Ryan. Interview 1. August 2017)

In this experience, Mr. Ryan began to develop the two domains of teacher professional identity (Beijaard et al., 2000). First, as a didactical expert, he knew that he should keep the learning objective on the right track even though he frequently changed media to achieve that learning objective. Second, as a pedagogical expert, he conducted many experiments in his class by applying various media by the aim to find the most suitable media for the students. It should be noted that his English mastery, as a subject-matter expert, had already gained far before his pedagogic and didactic domains.

Also, Mr. Ryan did pre-service teaching to have professional training. He got experience in teaching high school students who needed extra effort to attract their attention, especially for writing. At the time, he utilized pictures to encourage students' ideas. Then, he also performed in-service training to improve his teaching quality. He had utilized pictures in teaching, but he got a suggestion from his mentor that it was not suited for high or vocational students since they should receive a higher level of media rather than just pictures. Therefore, Mr. Ryan improved his teaching media into a more valuable one. In this point, he had an idea to use comics as the combination of pictures and words in teaching writing rather than pictures. 
"about teaching experiences, the teacher-trainee program, that was my only experience before I became a real teacher, teaching senior high school students, it was difficult to attract their attention to write, possibly because I only used some of the comics' pages. Mmm, while I am becoming a teacher, I got some developmental training or workshops to become more professional. Moreover, during that time, I got suggestions from the trainers or the instructors, so I could deeply explore the media; it is more than just ordinary pictures, so my students become smarter." (Mr. Ryan. Interview 1. August 2017)

Here, Mr. Ryan's pedagogical domain much more expanded than the others. His knowledge of the media was more in-depth than before. He also noted that in order to gain students' attention, using some comics pictures seemed to have an insignificant impact. From this case, Mr. Ryan realized that he should use something much better, such as digital comics. It sums up that teacher learning is the interconnection between practice, theory, and 'the person of the teacher' (Korthagen, 2016).

\subsection{The strategy to maximizing the use of digital comics}

The implementation was divided into four stages: preparation, brainstorming, drafting, and revising. These stages are the reflection of teaching, which implemented the genre approach. This approach emphasizes the learners to focus on the social purposes of the texts. The integration of this approach with comics was believed as the best decision based on the consideration of the students' interest, the teacher's experiences, and the teaching objective.

\section{Preparation stage}

Before implementing comics in teaching writing, Mr. Ryan did some preparations in order for him to present the effective teaching process and achieve the learning goal. In this study, he checked on the syllabus and material to plan a lesson. Then, he browsed on the internet to find suitable comics for having an adjustment to the material. He prepared comics for material and exercise. He also learned those comics in detail before taught it to his students.

"...matched it with the standard and the basic competence as provided in the syllabus, then I checked the lessons. Next, I searched for some sources or references for comics (on the internet). After that, I should understand its contents. That is impossible if I teach comics, but I do not understand it."(Mr. Ryan. Interview 2. September 2017)

Finding suitable comics and changing the comics' contents were some strategies which have already done. The learning materials, the lesson plans, and the syllabus are vital elements to keep the learning process on the right track.

Preparing the materials between descriptive and recount texts were different. For the material of the descriptive text, Mr. Ryan selected one of the comics' panels and replaced the original speech bubble which contains only one short sentence (Picture 1) with the new speech bubble which contains two or more complex sentences (Picture 2). Indeed, the new sentences were also suited to the character's face-expressions. 


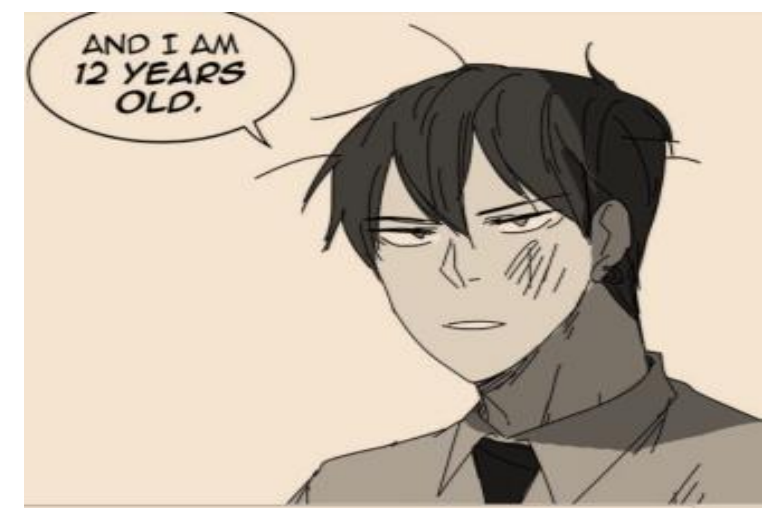

Picture 1. Original Speech-balloon

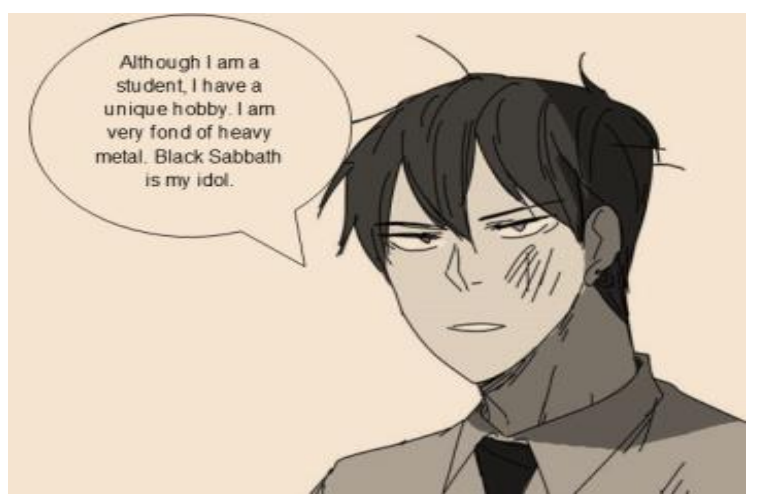

Picture 2. Adapted Speech-balloon

For the material of recount text, Mr. Ryan composed complete pictures and dialogues because it would cover the whole story. Nevertheless, he also changed the content of the story, so it was appropriate to the syllabus as a guideline which covered the material. As one of the comics' references, Mr. Ryan read and downloaded digital comics such as LINE Webtoon in its website www.webtoon.com/en

"...the one which is available on the internet, it is easy (to be accessed) and varied. Hmmm, webtoon." (Mr. Ryan. Interview 2. September 2017)

A Korean webtoon is different from a scanned version of print comics, and it is a new form in global comics market Japanese comics industries are leading (Jang \& Song, 2017). Most of their comics artists, or known as webtoons, are Korean. This website provides free access to read and download all of the comics. For the webtoon's readers, including Mr. Ryan, these digital comics are easier to read than printed comics because the panels of the story are arranged in vertical not in horizontal (Jin, 2015). This arrangement makes the readers feel comfortable to read it by scrolling on smartphones screen even though their which have limited screen dimensions (5-7 inch).

\section{Brainstorming stage}

In the interview before the class began, Mr. Ryan said that he usually showed some pictures which did not contain any words to activate the students' thought. Then, gradually, he mentioned some simple descriptive-vocabulary to describe the pictures. 
“...as the warming up activity for the students, usually I provided some pictures, without any English words or phrases to get their attention. So they could express their thoughts or perceptions first. After that, I gave some simple English vocabulary. $80 \%$ of them were interested, especially for the students who liked pictures; they were able to express their ideas." (Mr. Ryan. Interview 2. September 2017)

This practice supported Astuti's (2016) argument that gaining an exciting and motivating learning atmosphere is the teacher's responsibility. On the other side, the students have the responsibility to respond to the teacher's efforts. More precisely, these positive atmospheres can be achieved only if the teacher and the students are willing to be engaged.

In the classroom practice, Mr. Ryan began his descriptive-text lesson by introducing the textual devices (e.g., speech-balloons, captions, onomatopoeia) of comics to his students. He showed and explained it through LCD.

Mr. Ryan: OK, my students, let us see the elements of comics! Which one is the speech-balloon?" (showing pictures) Mr. Ryan:most you have already known them, but maybe some of you are still unfamiliar with them. They are Japanese comics. Yes, manga. You may understand them by enjoying the unique pictures and simple speech bubbles. What manga' titles that you have read?

Student A: Naruto, Sir!

Student B: One Piece!

Student C: For anime, I like Doraemon and Detective Conan!

(Observation 1. August 2017)

To avoid confusion for the students who were not familiar with comics, scaffolding knowledge towards the textual devices should be done first. All the mentioned comics above were Japanese comics which were popular among Indonesian readers. Based on the students' responses in this conversation also implied that many of them were familiar with Japanese comics. Furthermore, it is also essential to inform the students that Japanese comics use right-to-left reading sequence, which is different from conventional comics which use left-to-right reading sequence (Cheung, 2015). Indeed, these activities are essential to construct the students' knowledge gradually.

Next, to complete the warming-up activity, Mr. Ryan showed some pictures of the comics' characters to his students. He delivered some questions about the characters to trigger the students' enthusiasm and ideas. One of the students gave quick responses to it. This student answered the question by using English-Indonesia mixed-code because he forgot some English vocabularies.

"Naruto, Sir! He is a strong ninja. He wears a blue headband. There is a symbol of his birthplace in his ikat kepala. He has kumis like Doraemon in his pipi. He has many jurus untuk mengalahkan his enemies. (Student B. Observation 1. August 2017)

Mr. Ryan asked the student to express his ideas and did not interrupt him even though he used mixed language. He responded and corrected to the students' sentences after the students finished his answers. Using dictionaries and smartphone were allowed to help the students to find the vocabulary. 
"Bando is the Indonesian language. Use 'headband' to mean 'ikat kepala.'Then, find out about 'kumis', 'pipi', 'jurus', and 'mengalahkan'in English!' (Mr. Ryan. Observation 1. August 2017)

The use of mixed languages (L1 and L2) revealed the students' high enthusiasm, which spontaneously responded to the teacher's questions. It represented that their needs and knowledge are still constructing (Astuti, 2016). Another possibility, Mr. Ryan assumed that the direct correction was not necessary; mainly, it was still in the brainstorming stage. After the oral brainstorming, Mr. Ryan helped his students to practice written brainstorming. He guided the students to make a list of physical characteristics, which was mentioned in the speech-balloons on the whiteboard. Then, for the next several minutes, these students were asked to write more or make a list of what the other characteristics in the comics.

"...yes because the learning objective is the students should be able to write descriptive text, I guided them to elaborate the ideas first, so when they started to write descriptive paragraphs, they already have the concepts. Not all students have the ability to write the text without elaborating the concept first. That is why I gave them some times to think about what they wanted to write about the topics. Next, I asked them to make a list of ideas, and then they could continue to write the text." (Mr. Ryan. Interview 2. September 2017)

The oral brainstorming was usually done by the help of the teacher's guidance (e.g., the guided questions) while the written brainstorming was done independently by the students themselves (e.g., mind-map or shop-list). The students might use one or mix various techniques of brainstorming as far as it could help them in the drafting stage.

In this stage, Mr. Ryan practiced two techniques of brainstorming, oral and written. Commonly, the oral brainstorming was practiced first and then continued with the written brainstorming. Direct corrective feedback, especially in the oral brainstorming, is not recommended if it would delay the students to generate their ideas.

\section{Drafting stage}

To deal with the drafting stage, Mr. Ryan allowed his students to do this activity in a group so he could manage the time allotment efficiently by checking his students' drafts. He emphasized that the students should focus on the content and the meaning of the text and also reminded them not to worry about grammar or spelling mistake; nevertheless, those aspects were important in writing too. Creating a learning atmosphere where students felt worried less about making mistakes and making suggestions to improve their ability was important (Peterson \& Portier, 2014). Comics could assist the students with the sequence of stories in making a draft. When his students got confused about the continuance of the plot, they could see the comics. This point occurred while Mr. Ryan was teaching recount writing. Mr. Ryan also responded to students' questions and controlled their progress on drafting.

"...and because I used comics, they were more independent; they could read the pictures and the dialogues by themselves; only if they confused about how the story sequences were." (Mr. Ryan. Interview 2. Sept 2017)

The drafting stage was mainly representing the learner-centered activity, which revealed the students' readiness as autonomous learners. This finding supported the previous studies' (Astuti, 2016; Ferdiansyah, 2018) results that collaborative or group writing is a practical approach to 
promote students' collaborative endeavor, self-esteem, and confidence which are useful to build learning autonomy. After the students accomplished the drafting process, Mr. Ryan allowed them to write onto a text by developing the main ideas. He gave an example of how to generate the draft by showing his draft. He did not write beyond the draft.

"When I gave the model writing for the students, the models have never been too difficult, or something different from the earlier draft. I could do that, but they would confuse."(Mr. Ryan. Interview 2. Sept 2017)

It should be noted that the given an example or the model was given to teach the students on 'how to write' not 'what to write' (Badger \& White, 2000). Mr. Ryan wanted his students to learn how to think logically in order. Indeed, this was more than just copying or reproducing that model. Then, the students wrote a text in a pair. They might ask Mr. Ryan when they confronted difficulties. Mr. Ryan had a view that teaching writing was not testing writing, so he permitted his students to open standard or offline dictionary. However, they were not allowed to access Google Translate or other online dictionaries to prevent the misinterpretation in translating sentences. Mr. Ryan's assumption was in line with (Vidhayasai, 2015), who found that the mistranslation of Google Translate mostly occurred at the lexical level.

"If there are difficulties, you may ask me! However, do not use Google Translate instantly! Try to find the word of the meaning by word! Do not put the sentence or the whole text into google-translate!" (Mr. Ryan. Observation 1. Agt 2017)

Mr. Ryan recognized the potential of allowing the use of smartphones or laptops during the learning process. It promoted collaboration between the teacher and the students (Ekanayake \& Wishart, 2014). Students working with digital tools could evolve their creativity because their effort in visualizing the story was created by thinking of creative designs in their digital storytelling (Ferdiansyah, 2018). Here, Mr. Ryan emphasized three vital processes, i.e., the processes of developing ideas initially, the process of finding the words' meaning carefully, and the process of translating their sentences manually. These processes focused on developing the students' knowledge of how to write texts correctly.

During this stage, Mr. Ryan also observed that his students became more active while reading their digital or printed comics to rewrite the stories. Some of them were also busy with their dictionary. Since all the students were busy, Mr. Ryan checked the students' works by going around in the classroom.

"I realized that the students were more active; they were busy to involve in the writing process. Some students accessed comics via their smartphones, some others brought it from the house, and the rest of them were busy to find words in the dictionary, all of them were busy to write comics. I was so excited but also exhausted, because I had to go around checked their works." (Mr. Ryan. Interview 1. Agt 2017)

Loughran and Berry (2005) emphasized that teachers should make students aware of the pedagogical reasoning, feelings, thoughts, and actions that accompany practice across a range of teaching and learning experiences. Fortunately, Mr. Ryan was able to sense the positive response from his students while he was applying comics. He has a high level of awareness, intuition, and consciousness. This sensitivity is only possible to be acquired by the teachers who have a strong affection 
towards their students. These teachers will give their best to seek and try numerous ways to ease their students in learning. Moreover, the use of digital comics encouraged the students to engage with the current trend of technology.

To sum up, the drafting stage put more focus on the students' activities rather than the teacher's role. All of these students' activities were given to guide them to become autonomous learners. Meanwhile, the teacher was needed to observe the students' progress during these activities. Here, the teacher played a role as a guide and an observer.

\section{Discussing \& revising stages}

Mr. Ryan allowed his students to discuss what they had written with their peers. They might ask for some suggestions of the content and corrections of the grammar and usage in this proofreading stage. All of them became peer reviewers to check and improve their drafts. Mr. Ryan also took a sample of student's draft, and then he explained to his students how to review it. The review should be started by checking the content first before it went analyzing the grammar.

'The students' revising process took quite of time. It was not only involving my feedbacks but also the peers' feedbacks, as far as they can do. After the review on contents and grammar was done, the last step was the editing process."(Mr. Ryan. Interview 2. September 2017)

While having discussion and revision among students, Mr. Ryan also gave some comments on their work generally. He had some considerations; time and independent learners. He wished that his students could edit their writing after having the revision. In the revising process, the drafts received feedbacks from both sides; the teacher and the peers. Unfortunately, Mr. Ryan did not give the detail explanation on which area (e.g., content, grammar, and organization) that should (not) be reviewed by the peers. It might cause inefficiency because there was a possibility that the teacher's feedback would overlap with the peers' feedback (Arif \& Lestari, 2014). Furthermore, giving particular kinds of feedback had a significantly different effect on the quality of the students' writing (Saukah, Dewanti, \& Laksmi, 2017).

\subsection{The difficulties encountered by the students and the teacher}

There were two main difficulties. First, Mr. Ryan explained that he was not used to drawing comics by himself. Drawing comics spent much time, whereas he should prepare many other things before teaching. Furthermore, he also needed to edit some of the comics' contents.

“...ideally, I should draw it by myself, but I was not used to it. It took much time whereas this media was not the only one important thing which I should prepare before teaching. Moreover, after I download the comics, it still needed to be edited so it could match with the material." (Mr. Ryan. Interview 2. September 2017)

Second, there was a problem with the post writing activity because of time allotment. He understood that teaching writing needs entirely of time.

"to teach writing is time-consuming. Even with the time allotment, it was not enough. Moreover, I could not conduct the post-writing activity for the students. Consequently, that task was given as their homework" (Mr. Ryan. Interview 2. September 2017) 
The problem of adapting comics was not found in any previous study because the other teachers preferred to create their comics. Winarti et al. (2018) proved the usefulness of latest technology helped teacher or learners who wanted to create their digital comics. Those applications are Storyboard That ${ }^{T M}$, Cartoon Story Maker (CSM), MakeBeliefesComix Storybird, Toondoo, Bitstrips for Schools, Digital Storytelling, and BoomWriter. It seems that adapting comics is more complicated than creating a new one.

The time management problem was in line with Cheung (2015) and Wang (2014). In responding to this finding, the researchers assumed that it was correlated to the back-and-forth cycles of genre approach and the time preparation. The time allotment for English is only 135 minutes per week. The implementation of digital comics in a classroom needs to be supported with other electronic tools such as laptop, projector, and screen. This preparation needs approximately 10 minutes per meeting. It may need longer time if the tools do not work correctly. Although the problem of time allocation is inevitable, it can be minimized if the teacher can prepare and recheck all of his equipment before the implementation

\section{CONCLUSION}

The materials arranged for Linguistic Description of English is undertaken to fulfill the need for the learning and teaching process for LDoE subject. This subject is a new subject offered in the curriculum of English Education Study Program at Universitas Jambi and does not have the materials available for teaching activity in the class. By doing research and development, the material prototype has arranged that suits the need of the students as well as the lecturers. The prototype consists of two chapters about discussions on Morphology and Syntax. Each chapter generally contains several components, namely the unit title, lesson's objectives, unit discussion, and comprehension exercises. Even though the prototype of the materials has not been tested in field testing yet, the result of validation by expert validator indicates that the prototype can be used as the representative of the whole complete materials and the researcher are allowed to continue the development process until it becomes a comprehensive material for teaching LDoE later in the class.

\section{References}

[1] Abate, M. A., Grice, K. M., \& Stamper, C. N. (2018). Introduction: “Suffering Sappho!”: Lesbian content and queer female characters in comics. Journal of Lesbian Studies. https://doi.org/10.1080/10894160.2018.1449500

[2] Amerian, M., \& Pouromid, S. (2018). Language Teachers' Beliefs on Materials Use and Their Locus of Control: CaseStudies From Iran and Japan. Indonesian Journal of Applied Linguistics, 7(3), 583-593. https://doi.org/10.17509/ijal.v7i3.9808

[3] Anggraini, P. (2014). Manga Comics as Appealing Extensive Reading Materials for the Tenth Graders of Senior High School. In TEFLIN International Conference (pp. 343-346).

[4] Arif, M. D., \& Lestari, L. A. (2014). Students ' Responses Toward Peer Review in Writing. RETAIN, 2(3).

[5] Astuti, S. P. (2016). Exploring Motivational Strategies of Successful Teachers. TEFLIN Journal, 27(1), 1-22. https://doi.org/https://doi.org/10.15639/teflinjournal.v27i1/1-22

[6] Badger, R., \& White, G. (2000). A Process Genre Approach to Teaching Writing. ELT Journal, 54(2).

[7] Baudinette, T. (2017). Japanese Gay Men's Attitudes Towards “Gay Manga” and the Problem of Genre. East Asian Journal of Popular Culture, 3(1), 59-72. https://doi.org/https://doi.org/10.1386/eapc.3.1.59_1 
[8] Beijaard, D., Verloop, N., \& Vermunt, J. D. (2000). Teachers ' perceptions of professional identity : An exploratory study from a personal knowledge perspective Teachers ' perceptions of professional identity : an exploratory study from a personal knowledge perspective. Teaching and Teacher Education, 16, 749-763. https://doi.org/10.1016/S0742-051X(00)00023-8

[9] Cheung, K. (2015). Learning past the pictures in the panels : Teacher attitudes to manga and anime texts. Macquarie University, Sydney.

[10] Deligianni-Georgaka, A., \& Pouroutidi, O. (2016). Creating digital comics to motivate young learners to write: a case study. Research Papers in Language Teaching and Learning, 7(1), 233-263.

[11] Ekanayake, S. Y., \& Wishart, J. (2014). Integrating mobile phones into teaching and learning: A case study of teacher training through professional development workshops. British Journal of Educational Technology, 1-17. https://doi.org/10.1111/bjet.12131

[12] Elmiana, D. S. (2019). Pedagogical representation of visual images in EFL textbooks: a multimodal perspective. Pedagogy, Culture and Society. https://doi.org/10.1080/14681366.2019.1569550

[13] Ferdiansyah, S. (2018). Collaborative narrative writing: A digital photography task in an Indonesian Islamic secondary school. Indonesian Journal of Applied Linguistics, 8(2), 303-315. https://doi.org/10.17509/ijal.v8i2.13277

[14] Gabinete, M. K. L. (2017). Teachers' Beliefs and Practices in Assessing the Viewing Skill of Esl Learners. Indonesian Journal of Applied Linguistics, 7(1), 19-28. https://doi.org/10.17509/ijal.v7i1.6854

[15] Galvan, M. (2018). Making space: Jennifer Camper, LGBTQ anthologies, and queer comics communities. Journal of Lesbian Studies. https://doi.org/10.1080/10894160.2018.1449499

[16] Howard, S. C. (2018). Situating Cyberzone: Black lesbian identity in comics. Journal of Lesbian Studies. https://doi.org/10.1080/10894160.2018.1449992

[17] Issa, S. (2017). Comics in the English classroom: a guide to teaching comics across English studies. Journal of Graphic Novels and Comics. https://doi.org/10.1080/21504857.2017.1355822

[18] Jang, W., \& Song, J. E. (2017). Webtoon as a New Korean Wave in the Process of Glocalization. Kritika Kultura, 2017(29), 168-187. https://doi.org/10.13185/KK2017.02908

[19] Januarty, R.-, \& Azizah Nima, H. N. (2018). Energizing Students' Reading Comprehension Through Multimodal Texts. International Journal of Language Education, 2(2), 14-22. https://doi.org/10.26858/ijole.v2i2.4347

[20] Jin, D. Y. (2015). Digital convergence of Korea's webtoons: transmedia storytelling. Communication Research and Practice, 1(3), 193-209. https://doi.org/10.1080/22041451.2015.1079150

[21] Johnson, A. (2016). The Use of Graphic Novels to Support Struggling Fifth Grade Student Story Writing. St. Fisher College.

[22] Kedley, K. E., \& Spiering, J. (2017). Using LGBTQ Graphic Novels ot Dispel Myths about Gender and Sexuality in ELA Classrooms. English Journal, 107(1), 54-60.

[23] Kim, S. (2018). Exploring media literacy: Enhancing English oral proficiency and autonomy using media technology. Studies in English Education, 23(2). https://doi.org/10.22275/see.23.2.03

[24] Kiss, T., \& Weninger, C. (2016). Cultural learning in the EFL classroom: The role of visuals. ELT Journal, 1-11.

[25] Korthagen, F. (2016). Inconvenient truths about teacher learning: towards professional development 3.0. Teachers and Teaching: Theory and Practice. https://doi.org/10.1080/13540602.2016.1211523

[26] Liu, J. U. N. (2004). Effects of Comic Strips on L2 Learners' Reading Comprehension. TESOL Quarterly, 38(2), 225243.

[27] Loughran, J., \& Berry, A. (2005). Modelling by Teacher Educators. Teaching and Teacher Education, 21, 193-203. https://doi.org/10.1016/j.tate.2004.12.005

[28] McGrail, E., Rieger, A., \& Doepker, G. (2017). Pre-Service Teachers' Perceptions about the Effectiveness of the TOON Comic Books in Their Guided Reading Instruction. Georgia Educational Researcher, 14(1), 1-39. https://doi.org/10.20429/ger.2017.140101 
[29] Nordin, S. M. (2017). The best of two approaches : process / genre-based approach to teaching writing. The English Teacher, $X X X V, 75-85$.

[30] Osman, H. (2017). Genre-Based instruction for ESP. The English Teacher, XXXIII, 13-29.

[31] Park, J. (2016). "Breaking the word" and "sticking with the picture": Critical literacy education of US immigrant youth with graphic novels. English Teaching, 15(1), 91-104. https://doi.org/https://doi.org/10.1108/ETPC-08-20150065

[32] Peterson, S. S., \& Portier, C. (2014). Grade One Peer and Teacher Feedback on Student Writing. Education 3-13: International Journal of Primary, Elementary and Early Years Education, 42(3), 237-257. https://doi.org/10.1080/03004279.2012.670256

[33] Richardson, V. (1996). The Role of Attitudes and Beliefs in Learning To Teach. In I. J. Sikula (Ed.), Handbook of Research on Teacher Education (pp. 102-119). New York: Macmillan.

[34] Rokhayani, A., \& Utari, A. R. P. (2014). The Use of Comic Strips as an English Teaching Media for Junior High School Students. Language Circle: Journal of Language and Literature.

[35] Rozema, R. (2015). Manga and the Autistic Mind. English Journal, 105(1), 60-68.

[36] Salcedo, N., \& Sacchi, F. (2014). The role of culture in the EFL classrooms: A study of teacher's beliefs and practices.

[37] Saukah, A., Dewanti, D. M. I., \& Laksmi, E. D. (2017). The Effect of Coded and Non-Coded Correction Feedback on the Quality of Indonesian Efl Students' Writing. Indonesian Journal of Applied Linguistics, 7(2), 247-252. https://doi.org/10.17509/ijal.v7i2.8127

[38] Susilawati, F. (2017). Teaching Writing of Narrative Text through Digital Comics. Journal of English and Education, 5(2), 103-111.

[39] Unser-Schutz, G. (2015). Influential or influenced? The relationship between genre, gender and language in manga. Gender and Language, 9(2), 223-254. https://doi.org/https://doi.org/10.1558/genl.v9i2.17331

[40] Utami, I. G. A. L. P. \& Prestridge, S. (2018). How English teachers learn in Indonesia: tension between policy-driven and self-driven professional development. TEFLIN Journal, 29(2), 243-265.

[41] Vega, J. (2015). Making the Case for LGBT Graphic Novels. Language Arts Journal of Michigan, 20(2), 39-43. https://doi.org/https://doi.org/10.9707/2168-149X.2070

[42] Vidhayasai, T. (2015). Investigating the Use of Google Translate in "Terms and Conditions " in an Airline's Official Website : Errors and Implications. PAASA, 49, 137-169.

[43] Wang, W. (2014). Students' perceptions of rubric-referenced peer feedback on EFL writing: A longitudinal inquiry. Assessing Writing, 19, 80-96. https://doi.org/10.1016/j.asw.2013.11.008

[44] Winarti, H., Masrupi, \& Juniardi, Y. (2018). English Digital Comics for the Students of Senior High School in Banten. In AISELT (pp. 231-240).

[45] Yin, R. K. (2014). Case study research: design and method (5th ed). Thousand Oaks: SAGE.

[46] Yusof, S. M., Lazim, Z. M., \& Salehuddin, K. (2017). Teacher Trainees' Perspectives of Teaching Graphic Novels to ESL Primary Schoolers. 3L: The Southeast Asian Journal of English Language Studies, 23(3), 81-96. https://doi.org/10.17576/3L-2017-2303-06 